\title{
Creating Student Engagement? HMM: Teaching and Learning with Humor, Music, and Movement
}

\author{
William B. Strean \\ University of Alberta, Alberta, Canada. \\ Email: billy.strean@ualberta.ca \\ Received April $7^{\text {th }}$, 2011; revised May 4 $4^{\text {th }}, 2011$; accepted May $17^{\text {th }}, 2011$.
}

\begin{abstract}
With growing concerns about student engagement, the theme of creative teaching and learning provides an excellent catalyst to consider methods that enhance students' classroom experiences. Good teaching is akin to weaving a fabric of connectedness between student, teacher, and subject (Palmer, 2007). Teacher-student connection and student engagement are the two most important ingredients in teaching (Lowman, 1995). This paper explores three effective methods of weaving the fabric and engaging students in higher education. Examples of how to use humor, music, and movement to deepen learning while adding energy, engagement, and interaction are offered. A review of research supporting the methods explored in this paper is included.
\end{abstract}

Keywords: Student Engagement, Humor, Music, Movement

I'm going to begin with a joke so we can get the humor out of the way. Although that may have been a joke (you can check to see if you were amused), the perspective that I will advocate here is that humor is not about telling jokes and not essentially about getting laughs. Humor is fundamentally about a mood of lightness that facilitates learning. In virtually any learning environment, students enter with some level of tension, anxiety, and/or resistance. If the stress response is activated, it can decrease the brain's capabilities to learn and remember (Kaufeldt, 2010). An atmosphere of humor helps to dissipate negative emotions that can impede learning. So lighten up. You have arrived at a place in life where you have the luxury of reading an article about creative education. Relax and consider how the ideas and suggestions that follow may enhance your students' engagement and perhaps enliven your own teaching experiences.

\section{A Somatic Perspective}

Somatics provides a valuable way of considering our students and our selves that informs and supports the use of humor, music, and movement in learning. Please bear with the seriousness for a few moments as it provides an important rationale for why the particular approaches advocated here are valuable in enhancing engagement and learning. The term "somatics," comes from soma - the body in its wholeness. From a somatic perspective, we cannot distinguish the self from the body. The characteristics that constitute the self (emotions, actions, beliefs, interactions, perception, ethics, morals, and drive for dignity) all emerge from the physical form (e.g., Strozzi-Heckler, 2003; 2007). Somatics rejects the notion that there is a disembodied, self-contained self that is separate from the life of one's body. Clearly these ideas depart drastically from pervasive Cartesian discourses that have dominated and also posited a determinable, objective reality disconnected from subjective experience (Strean \& Strozzi-Heckler, 2009). The loss of somatic knowing and the worldview derived from Descartes’s dualism carries its own logical conclusion: Since I do not have immediate contact with any of the realities of my ordinary life, I can be deluded about any of them (Johnson, 1983).

Most of our understanding of the mind and rationality are based on metaphors that are not supported by cognitive science. Take for example the enduring notion that rational thought is dispassionate. We know this to be false from studies in neuroscience (Damasio, 1994). Those who have lost the capacity to be emotionally engaged in their lives cannot reason appropriately about moral issues. The traditional Western conception of the person with disembodied reason and an objective world must be replaced with the conception of an embodied person. Among the important implications for teaching and learning is the recognition of the centrality of emotion. All learning occurs in a mood and part of fostering student engagement includes attending to and managing the mood of the classroom.

"It is anybody's guess as to how many of us ... walk around in schools and universities with feelings of bodily and emotional stress because of the disembodiment involved in how we are taught to teach, to learn, and to do research. Probably there are hordes of us. As we become adults, we learn how to repress somatic awareness, and many of us can no longer tell when our stomachs know better than our minds, when our bodies feel completely wrong, or why we develop headaches. We cover up the stress caused by the disembodiment of our work by still more work, or by still another cup of coffee. Lack of meaning, which points, by definition, to the loss of a participatory way of knowing, to lack of somatic and emotional involvement (see Berman, 1989; Johnson, 1983; Tarnas, 1991), is no longer accurately felt, understood, and acted on (Heshusius \& Ballard, 1996: p. 3).”

Humor, music, and movement can reawaken our somatic awareness and assist fuller and deeper learning experiences. A couple of quotations that speak to somatic approaches to education are

"Book learning tends to stay in the book" and "Learning is a 
myth until it is embodied” (Strozzi Heckler, 1993). The frameworks and classroom practices I will address are about getting learning into the body. Parker Palmer (2007) tells us that good teaching is akin to weaving a fabric of connectedness between student, teacher, and subject. Three effective methods of weaving the fabric and engaging students are humor, movement, and music.

\section{Student Engagement}

The phrase "student engagement" has come to describe "how involved or interested students appear to be in their learning and how connected they are to their classes, their institutions, and each other” (Axelson \& Flick, 2011: p. 38). Today's students have been accused of presenting an attitude of just wanting the information the teacher wants them to know for the test and they presume that they will then both get what they need (Barkley, 2010). There is a continuum of what is meant by "student engagement" and a concomitant range of benefits from grabbing attention to facilitating deep learning. Particularly in higher education, where there tends to be increased focus on the cognitive domain and decreased concentration on physical and emotional considerations, it is valuable to include classroom approaches that begin with enhancing attention and move toward deepening learning.

\section{Warm-up}

After reading a few mind-numbing paragraphs you may be convinced of some academic currency undergirding the lighthearted adventures that are about to follow, but you may also be feeling your first taste of sluggishness. Among the benefits of humor, music, and movement is increasing students' (and your) aliveness. Although the full version is probably not warranted in most contexts, one way to get ready to learn is BrainDance (Gilbert, 2006). The BrainDance is a series of exercises including eight fundamental movement patterns that we move through in the first year of life. These patterns are crucial to the wiring of our central nervous system. As babies, we did these movements on our tummies on the floor, but students may be reluctant to go to that extreme and it may also muss the professor's tweed jacket. However, cycling through these patterns sitting or standing has been found to be beneficial. This "dance" is an excellent full body and brain warm-up for children and adults in all settings. The BrainDance can be done at the beginning of class; before tests, performances, and presentations; and during computer work and TV watching for brain reorganization, oxygenation, and recuperation. Ideally you would stand up now and get the somatic experience of BrainDance, but unless you have participated previously, you'll just have to take my word for its awesomeness. (More information is available at http://www.creativedance.org/about/braindance.cfm)

\section{Opening Sounds}

In many learning environments, there is not the time or inclinations for something as elaborate as BrainDance, but there are other ways to grab attention and to create a mood of lightness or playful exploration. One use of music is playing a clip right at the start of class. Some of my favorites include "Get Ready for This" (2 Unlimited) and "Let's Get it Started” (Black Eyed Peas). Depending on your/students' musical tastes you might prefer "Start Me Up" (Rolling Stones) or "Wanna Be Startin' Something” (King of Pop, RIP). For an early morning class, a bugle sound of revile might fit the bill. In addition, other sound clips like the Three Stooges saying "Hello, Hello, Hello," or Barbara Walters from 20/20, "What you are about to hear is bizarre, unsettling, and riveting" can engage the crowd and help you to grab everyone's attention. Another effective use of music is to have background music playing as students are entering class to set a particular mood such as curious (e.g., "Questions”) or energized (e.g., "Pump UP the Jam”), or relaxed (e.g., reggae or "Ave Maria” but not "Relax" by Frankie Goes to Hollywood). You can enjoy your own creativity by selecting music and sounds for a chosen purpose.

\section{Be-Do-Have}

The use of humor, music, and movement, and, perhaps, all of teaching depends on the ontological status of the teacher. More simply put, "who you are being” is decisive. The Be-Do-Have model provides a useful way to inquire into how we approach our teaching. Most of us tend to live our lives backwards from this model. You have probably heard yourself or those around you say, "If I had more time...” or "If I had more money...” then I would be happy. Such an approach may be swimming upstream against the "appropriate flow of life." The underlying idea of beginning with being has probably been around for thousands of years, but it is not part of our contemporary conversations. Did you ask yourself how you want to be today as you read this article? No. It would probably be a bit weird if you did. What if we pause before we enter our classrooms and say, "I'm going to go to teach anyway, I may as well choose how I'm going to be.” What would be a good way for you to be right now? Inquisitive? Curious? Amazed? Amused? Happy? It is pretty clear that we have a great deal more power to select our ways of being than we tend to use. Although adding humor, music, and movement to your teaching may be good things to "do," if you can bring a mood of lightness and generate a way of being that supports student engagement, the actions you take will be fantastically more effective.

\section{Further Rationale}

The literatures on attention problems in lectures as well as patterns of discussions in groups support the merits of all the approaches suggested here. An additional ground for including humor, music, and movement in our classes emerges from our understanding of attention span in lectures. Various reports (Bligh, 2000; McKeachie \& Svinicki, 2006; Young, Robinson, \& Alberts, 2009) demonstrate that when listening to a lecture, attention drops precipitously after 10 to 30 minutes. Various teachers seek to contest attention problems with straight lecture by using discussion. Yet, studies of student participation in such discussions found that in groups of five, the most engaged person contributes $43 \%$ but the least engaged member only contributes 7\%; in groups of eight, the least engaged five members contribute a mere 3 to $9 \%$ (Gibbs, 1992). 


\section{Like to Move It Move It}

Because of these issues of attention span, a great way to increase energy and engagement is with physical movement. It is ideal when movement can be incorporated directly with the learning objectives of the day (see below), but short activities simply to shift attention and awaken the students is beneficial. Again, you can use your creativity to invent options that work best in your context. Some examples include having all the students do some imaginary biking or hiking in their chairs. Or you might have a real or imagined ball that students pass around the room. It could be as basic as a simple 'stand, stretch, and breathe' moment. Personally, I enjoy laughter exercises as they have the multiple benefits of mood enhancement, increased oxygen, and playful movement. In a general sense, movement can facilitate learning, enhance class cohesion, offer an environment that promotes laughter and fun while engaging learners, and heighten students' interest in attending and participating in class (Lengel \& Kuczala, 2010). There are times when I've noticed either at the start of a class or during a session, that the group seems lethargic. (This happens frequently during midterm week.) By having everyone stand up and do some playful activities, it easily produces some laughs, increases the energy level, and gets the group more engaged in the learning that will follow.

A variety of movements and activities can be essential in getting learning "into the body." The general point is rather than speaking about a concept, students can live it. For example, instead of a discussion of rapport, students could work in pairs and do exercises that involve mirroring or a two-step. Other examples of using movement to teach bodily dispositions of leadership, flow and optimal performance, and how to embody humor have been elaborated previously (Strean, 2010).

\section{How about Humor?}

Although learning is serious business, heaviness and negative emotions can get in the way of successful pedagogy. In addition to fostering valuable lightness, humor builds the teacher-student connection (e.g., Berk, 1998), and this connection is essential for learning, satisfaction, and retention. Research demonstrates that with humor, students learn better and remember more; and absorb information more quickly and retain it longer (e.g., Bryant \& Zillman,1989; Opplinger, 2003; Schmidt, 2002). Furthermore, humor can aid teaching by providing amusement, breaking up content, bringing back attention, lightening the mood, increasing motivation, reducing monotony, and providing a mental break (Neumann, Hood, \& Neumann, 2009). Humor increases students' enjoyment of learning, perceptions of how much they learned and positive feelings about the course and instructor (Wanzer \& Frymier, 1999). Baumgartner and Morris (2008) showed humor-based teaching is clearly more engaging and interesting for the students and incorporating humor into the classroom can have a positive effect on learning in higher education. Interested readers can find more information on both the benefits of laughter and humor and specific strategies to use humor in the classroom elsewhere (e.g., Berk, 1998; Strean, 2008).

Personally, I have found one of the easiest ways to incorporate humor into my classes is using myself as the easy target.
By poking fun at myself, I can decrease the distance between students and "the professor." By showing my own humanity and foibles, I believe I make it easier for students to relax and to take risks. At the beginning of an activity class where students were about to participate in some novel tasks and I felt some anxiety in the group, I told them how one of their peers suggested I remind her of Sue Sylvester (the character from Glee who is a ruthless bully to both students and faculty members). Perhaps I had worn too many matching track suits to class-but in sharing this comment and suggesting I was not flattered, the class had a good laugh at my expense and they seemed tangibly more at ease to purse the learning of the day.

\section{More about Music}

Music can humanize, personalize, and energize courses; tap into students' interests, and elicit positive feelings and associations; and involve students in relevant and meaningful interaction (Dunlap \& Lowenthal, 2010). From a physiological perspective, there is growing evidence that music can effectively elicit highly pleasurable emotional responses (e.g., Krumhansl, 1997; Rickard, 2004). Neuroimaging studies have confirmed those responses and shown "enhanced functional and effective connectivity between brain regions mediating reward, autonomic, and cognitive processing provides insight into understanding why listening to music is one of the most rewarding and pleasurable human experiences” (Menon \& Levitin, 2005: p. 175). Interestingly, music-induced emotional states have been linked to dopamine release, the chemical that sends "feel good” signals to the rest of the body (Salimpoor, Benovoy, Larcher, Dagher, \& Zatorre, 2011).

"Music speaks directly to the emotions. It allows us to be in touch with the pulse of life.” (Julio Olalla, personal communication, October, 2005). Music bypasses the cognitive filters and works wonders in a variety of ways to enhance student engagement. In addition to setting a mood or increasing energy, a well-chosen music clip can help to reinforce a learning point.

\section{Closing Sounds}

Just as we saw how opening sounds and music can create a mood or grab attention, finishing class with appropriate sound clips can be a reminder to leave on a light note. For example "This is the end" (The Doors), "Tune in tomorrow, same bat time, same bat channel” (from the TV Show, Batman), "and so we come to another fun-filled episode of Rocky and Bullwinkle” (guess), or "Ladies and gentlemen, we're desperately short on time, thanks for watching, good night everybody" (David Letterman) can all work nicely in the right context. In that spirit, let us move toward a finish with the lyrics of Carol Burnett:

I'm so glad we had this time together,

Just to have a laugh, or sing a song.

Seems we just get started and before you know it

Comes the time we have to say, "So long”.

\section{Conclusion}

Increasing student engagement is serious business. Paradoxically, bringing some lightheartedness to the process tends 
to make us more effective. As we ponder and explore various methods to connect with and to engage our students, humor, music, and movement appear to be three valuable methods.

\section{References}

Axelson, R. D., \& Flick, A. (2011). Defining student engagement. Change, 43, 38-43. doi:10.1080/00091383.2011.533096

Barkley, E. F. (2010). Student engagement techniques: A handbook for college faculty. San Francisco, CA: Jossey-Bass

Baumgartner, J. C., \& Morris, J. S. (2008). Jon Stewart comes to class: The learning effects of America (the book) in introduction to American government courses. Journal of Political Science Education, 4, 169-186. doi:10.1080/15512160801998015

Berk, R. (1998). Professors are from mars, students are from snickers: How to write and deliver humor in the classroom and in professional presentations. Madison, WI: Magna Publications.

Bryant, J., \& Zillman, D. (1989). Using humor to promote learning in the classroom. In P. E. McGhee (Ed.), Humor and children's development: A guide to practical applications (pp. 49-78). New York: Haworth Press.

Bligh, D. A. (2000). What's the use of lectures? San Francisco: JosseyBass.

Damasio, A. R. (1994). Descartes' error: Emotion, reason and the human brain. New York: Grosset/Putnam.

Dunlap, J. C., \& Lowenthal, P. R. (2010). Hot for teacher: Using digital music to enhance students' experience in online courses. TechTrends: Linking Research and Practice to Improve Learning, 54, 58-73.

Gibbs, G. (1992). Discussion with more students: Book 3 of the teaching more students project. Oxford: Polytechnics \& Colleges Funding Council.

Gilbert, A. G. (2006). Brain compatible dance education. Reston, VA: National Dance Association.

Heshusius, L., \& Ballard, K. (Eds.) (1996). From positivism to interpretivism and beyond: Tales of transformation in educational and social research (the mind-body connection). New York: Teachers College Press.

Johnson, D. (1983). Body. Boston: Beacon Press.

Krumhansl, C. L. (1997). An exploratory study of musical emotions and psychophysiology. Canadian Journal of Experimental Psychology, 51, 336-352. doi:10.1037/1196-1961.51.4.336

Kaufeldt, M. (2010). Begin with the brain: Orchestrating the learnercentered classroom. Thousand Oaks, CA: Corwin

Lengel, T., \& Kuczala, M. (Eds.) (2010). The kinesthetic classroom: Teaching and learning through movement. Thousand Oaks, CA: Corwin Press.

Lowman, J. (1995). Mastering the techniques of teaching (2nd ed.). San Francisco: Jossey-Bass.

McKeachie, W. J., \& Svinicki, M. (2006). McKeachie's teaching tips:
Strategies, research, and theory for college and university teachers (12th ed.). Boston: Houghton-Mifflin.

Menon, V., \& Levitin, D. J. (2005). The rewards of music listening: Response and physiological connectivity of the mesolimbic system. NeuroImage, 28, 175-184 doi:10.1016/j.neuroimage.2005.05.053

Neumann, D. L., Hood, M., \& Neumann, M. M. (2009). Statistics? You must be joking: The application and evaluation of humor when teaching statistics. Journal of Statistics Education, 17, 16 pages

Opplinger, P. A. (2003). Humor and learning. In J. Bryant, D. RoskosEwoldsen, \& J. R. Cantor (Eds.), Communication and emotion: Essays in honor of Dolf Zillman (pp. 255-273). Mahwah, NJ: Lawrence Erlbaum Associates.

Palmer, (2007). The courage to teach: Exploring the inner landscape of the teacher's life (10th anniversary ed.). San Francisco: Jossey-Bass.

Rickard, N. S. (2004) Intense emotional responses to music: A test of the physiological arousal hypothesis. Psychology of Music, 32, 371-38. doi:10.1177/0305735604046096

Salimpoor, V. N., Benovoy, M., Larcher, K., Dagher, A., \& Zatorre, R. J. (2011). Anatomically distinct dopamine release during anticipation and experience of peak emotion to music. Nature Neuroscience, 14 , 257-262. doi:10.1038/nn.2726

Schmidt, S. R. (2002). The humor effect: Differential processing and privileged retrieval. Memory, 10, 127-138. doi:10.1080/09658210143000263

Strean, W. B. (2008). Evolving toward laughter in learning. Collected Essays on Learning and Teaching, 1, 165-171.

Strean, W. B. (2010). Moving (literally) to engage students: Putting the (physically) active in active learning. Collected Essays on Learning and Teaching, 3, 33-37.

Strean, W. B., \& Strozzi-Heckler, R. (2009). (The) Body (of) Knowledge: Somatic contributions to sport psychology. Journal of Applied Sport Psychology, 21, 91-98. doi:10.1080/10413200802575726

Strozzi Heckler, R. (1993). The anatomy of change. Berkeley, CA: North Atlantic.

Strozzi-Heckler, R. (2003). Being human at work: Bringing somatic intelligence into your professional life. Berkeley, CA: North Atlantic Books.

Strozzi-Heckler, R. (2007). Leadership dojo. In P. Holman, T. Devane, \& S. Cady (Eds.), The changehandbook (2nd ed., pp. 239-243). San Francisco: Berrett-Koehler.

Wanzer, M. B., \& Frymier, A. B. (1999). The relationship between student perceptions of instructor humor and students' reports of learning. Communication Education, 48, 48-62. doi:10.1080/03634529909379152

Young, M. S., Robinson, S., \& Alberts, P. (2009). Students pay attention! Combating the vigilance decrement to improve learning during lectures. Active Learning in Higher Education, 10, 41-55. doi:10.1177/1469787408100194 